\title{
BILL GATES COVID-19 CONSPIRACY IN REDDIT MEMES: A SEMIOTIC APPROACH
}

\author{
AZKA SAEFUL HAQ ${ }^{1}$, INTAN SITI NUGRAHA ${ }^{1}$ \\ ${ }^{1}$ Department of Linguistics, Faculty of Cultural Sciences, Universitas Padjadjaran, Indonesia \\ azka19001@mail.unpad.ac.id
}

\begin{abstract}
Covid-19 as a global issue connects other social variables such as Bill Gates conspiracy issue discussed globally in public (Shalini, 2020). Memes as meaningful entities exist to influence the internet public in facing Bill Gates issue even without rational and empirical inquiry for some particular people that believe in them. Reddit as an easily accessible website shares actively more numerous memes related to Bill Gates conspiracy issue than the other websites. The memes contain cultural values represented by verbal and visual forms to exchange belief and rational arguments.This study is the interpretation data based on qualitative mtethod. Associating particular signifiers to Bill Gates in whole data refers to Bill Gates' negative track record, past ideas, ambitions, and pace. Several data contain visual and written signifiers that support each other to acquire signified in data such as Bill Gates in virus form who injects an old man. Signifiers reflect predominantly negative associations related to Bill Gates. It explicates negative connotation that exists consistently. Myths that exist represent that Bill Gates's vaccine as a danger, Bill Gates as a mastermind behind the pandemic, and Bill Gates as an opportunist who concerns about expansion of business to reach vaccine business.
\end{abstract}

Keywords: Bill Gates conspiracy, connotation, COVID-19, memes, myth

\begin{abstract}
ABSTRAK
Covid-19 sebagai isu global menghubungkan variabel sosial lainnya seperti isu konspirasi Bill Gates yang paling dominan dibahas secara global di ruang publik (Shalini, 2020). Meme sebagai entitas bermakna hadir untuk mempengaruhi publik internet dalam menghadapi isu Bill Gates, bahkan tanpa penyelidikan rasional dan empiris bagi sebagian orang tertentu yang mempercayainya. Reddit sebagai website yang mudah diakses secara aktif membagikan lebih banyak meme terkait isu konspirasi Bill Gates dibandingkan dengan website lainnya. Meme mengandung nilai-nilai budaya yang direpresentasikan dengan bentuk verbal dan visual untuk saling bertukar keyakinan dan argumentasi rasional. Penelitian ini merupakan interpretasi data berdasarkan metode kualitatif, yakni dengan jalan mengaitkan penanda tertentu kepada Bill Gates di seluruh data yang mengacu pada rekam jejak negatif, ide, ambisi, dan kecepatan Bill Gates. Beberapa data berisi penanda visual dan penanda tertulis yang saling mendukung untuk memperoleh tanda dalam suatu data seperti Bill Gates dalam bentuk virus yang menyuntik orang tua. Penanda tangan mencerminkan asumsi negatif terkait Bill Gates. Hal ini menjelaskan konotasi negatif yang ada secara konsisten. Mitos yang ada menunjukkan bahwa vaksin Bill Gates sebagai bahaya, Bill Gates sebagai dalang pandemi, dan Bill Gates sebagai seorang oportunis yang peduli pada ekspansi bisnis untuk menjangkau bisnis vaksin.
\end{abstract}

Kata Kunci: Konspirasi Bill Gates, konotasi, COVID-19, meme, mitos 


\section{INTRODUCTION}

Internet memes are encompassed through expressing values, ideas, and evaluations toward something based on cultural views. Studying memes can not be portrayed separately with values of culture so can ideas and evaluations (Achaidat, 2013; Cannizzaro, 2016; Dewi et al., 2017; Ross et al., 2017; Walker, 2004). Memes represent a different culture and are broadly spread in various types of social media and particular websites that are globally accessible for public use. They involve numerous activities formulated in study (Benaim, 2018) that notes many activities outside signification generated goods and services such as new products (books, DVD, merchandising), new platforms, a new approach to marketing, new brands, and even new firms of money after the existence of memes. Finally, the studies around memes stress "role of the visual in our world" (Foss, 2004). In the specific scope of signification, internet memes are not only reflecting specific ideas and information but also conveying them that can be consumed by the internet public.

Internet memes are digitally shared by a particular group and concerned with trending issues. They can reflect the construction of meaning that links to a particular ideological practice in a cultural commodity (Wiggins, 2019). They as meaningful entities exist to influence the internet public in facing an issue even without rational and empirical inquiry for some particular people that believe in them. Although the spreading is on a microlevel but its significance is in the macro one that shapes behavior forms, way of thinking, and actions of social groups (shifman, 2014). Covid-19 pandemic as global issue connects other social variables. One of the global trending issues refers to conspiracy issues relates to coronavirus disease 2019 (Covid-19) that emerges fast around the globe such as China's biological weapon and technology radiation. Investigating the most predominant Covid-19 issue, Bill Gates conspiracy issue becomes the most popular issue discussed globally in public (Shalini, 2020). Numerous representations related to Bill Gates and what affiliate to him can be found easily in digital activities. The emergence of memes relate to him reflects how a particular internet society portrays a global issue.

Conspiracy issue which contains a particular worldview emphasizing itself in three principles. First, nothing happens by accident view portrays a reality intentionally. Second, nothing is as it seems view thinks that appearance is deceptive. Third, everything is connected view believes that patterns are everywhere because of no room for the accident. A universe that is governed by design is implied by a conspiracist theory (Barkun, 2003). Relating to conspiracy theory in website, the indispensable manifestation of society is not a website but is only a virtual place. Acquiring aberrant decoding that will entail conspiracy theory is resulted by failing to view the difference between website and reality (Thibault, 2016). In the case of Bill Gates, it might happen as well and simultaneously represent the myth shared on the website. Trust, or distrust in facing his issue, the memes with its contsruction of meaning exist in digital rooms.

One of particular memes websites which still exists since 2005 is Reddit (reddit.com) with its online discussion of trending topics involving numerous users. It is documented from May 2019 until February 2020 that this American website had been visited by over 1.250 millions users (Clement, 2020). This easily accessible website becomes one of memes website that shares actively more numerous memes related to Bill 
Gates conspiracy issue than the other websites. Memes in this website can produce public opinion and they are usually reposted in different social media such as Twitter and Facebook. Memes in this context reflect belief and rational arguments related to cultural practice. They contains cultural values represented by verbal forms and visual forms to exchange belief and rational arguments. Memes convey and imply rapidity a new form of meaning-making that underscore their importance (Wiggins, 2019). In this study, memes of Bill Gates conspiracy issue confirm myth to portray as a delegated website discussing the same issues. Reddit as founded website by American people and mostly used by American user portrays Bill Gates as his American brother in global context with particular construction of meaning.

Memes are compatible with semiotics analysis that explicate signification for sign use. The memes terminolgy is a new word before other common conventional signs but not a new concept. That terminology only refers to a new version of sign as traditional semiotic concept (Kilpinen, 2008). Memes which are viewed as signbased phenomenon can be explained in focusing on visual and textual element in semiotic analysis. To reveal what kind of manifestation in memes, semiotics can also be used as a theoretical framework to study sign-based phenomenon (Sebeok, 2001). Comprehending signs is routine activity of public for human being can not access reality, values, and information without signs as a mediator. In acqiuring meaning of signs, human being creates life of sign in social life in representing anything and interpreting it (Danesi \& Perron, 1999).

Several previous research related to this study are myth of american cultural values in 9GAG memes website (Aditya Achadiat, 2013). It constructs meaning that affiliates to materialism, equality, freedom, and informality existing in forms of visual and textual signifiers. Public around the world especially the 9GAG visitors accept ideological values of USA in 9GAG "Hot Page". The other study conducts myth refered to political entity as a piece of social media to shape particular reality based on memes (Shteynman, 2016). It automatically does same activity to construct public opinions. It is similar with the other study that reveals political culture of indonesian social media public in Jakarta gubernatorial election (Dewi, Abdulllah, Maryani, \& Suganda, 2017). Memes combined with hoax phenomenon (Salam, 2018) was investigated through Barthes theory as well. It portrays that hoaxes do not correlate to institutional memeory of 'sacred argument' or symbolic manifestation regarding diversity of the nation, but are only employed for contemporary power struggles. Finally nothing become changed in modern structure established although the power struggle can evoke the people position in power to change. Studying myth can reflect a particular ideology in signs as these semiotic studies have been conducted (Achaidat, 2013; Mcilwain, 2007; Octavita et al., 2018). This present study aims to investigate the second order signification and myth in memes that finally shapes stereotypes of Bill Gates.

Culture which is dynamic manifestation of human's creation produces connotation to create new signification of a same signifier. Sign users are allowed to expand creatively the application of signs in their sociocultural life (Danesi, Messages, Signs, and Meanings 3rd edition, 2004). When someone grows and interacts through signs using, he/she adapts in signmaking to specific culture with signifying order. It is 'restrictive' characteristic of 
culture that defines signification but in the other hand other cultural characteristic such as 'liberating' encompasses sign users to add conventionally new constructions of meaning (Danesi \& Perron, Analyzing Culture, 1999). Moving from first-order meaning to second-order meaning or connotation reflect specific cultural practice in signification. New meaning from connotation contains particular vision of a group. Mantaining connotative meaning in a particular sign user can cause the transformation of constant connotation to a myth.

Myths refer to a message or a system of communication (Barthes, Mythologies (English Translation), 1972). Since myths become a type of speech, they which are conveyed or implied in a discourse form can emerge form everything, included signs. Encompassed by signification, they spread in social life to complement ideas related to any social context. Their natural characteristics and even timeless are accepted but in fact, a specific ideological vision hides in them (Allen, 2003). When a particular society accepts meaning construction of an issue, natural characteristic adheres in that issue as if it is really natural. There are other system which is used instead of dennotation to expand signification, namely connotation. Both first and second order of signification contain signifiers and signifieds that become parameter to distinguish. Plane of expression is constituted by the plane of signifiers and plane of content is constituted by the plane of signifieds (Barthes, 1967).

\section{METHOD}

This study is interpretation data based on qualitative method. The internet memes as data are spreaded specially in Reddit websites for its user and generally in Google Search related to Reddit website. Data acquired from amp.reddit.com are pictures which authentically refer to Reddit website. Even data can be accessed in Google Search related to Reddit website to match picture originality. Moreover, collocation keywords like conspiracy, vaccine, memes, meme, covid, corona, and cartoon memes are combined in Bill Gates as main keyword in searching process to gain data in Reddit website since last month in 2019 up to early 2020 posts. Data reduction is commited through concerning main topics namely Bill Gates conspiracy in COVID-19 pandemic. Finally, to analyze and discuss data, semiotic analysis is using Barthes' Myth theory. Semiotic analysis emerge to interpret relation to broader system meaning and it can access materials of visual culture (Rose, 2016). To avoid bias interpretation, composing interpretation is conducted in comparing visual signifier and written signifier.

\section{RESULTS AND DISCUSSION}

\section{Results}

These sample memes are delegated based on its similar signifiers to whole 16 memes found in Reddit. Undescribed memes contain similar patterns such as Bill Gates and vaccines or he as mastermind behind COVID-19

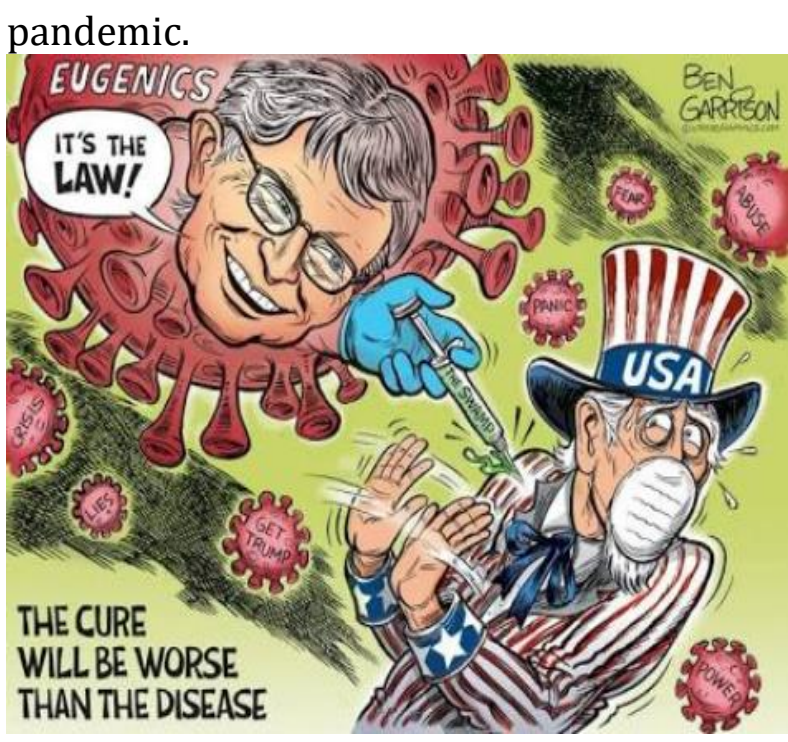

Fig. 1: Bill Gates and USA 
Although this meme is cartoon version of a real figure, the essence of internet memes are marked by visual and verbal interplay to propose or counter opinions (Wiggins, 2019). This meme produces visual and written signifiers that frame Bill Gates position and what he does to his environment. Signifiers found visually are vaccine, small viruses, Bil Gates' big virus, and the United States in an old man image. The viruses represent conspirary between Bill Gates and crisis, lies, power, abuse, etc. to create new worse condition in the Unites States. Thoses viruses also connect Bill Gates with a commune with same form as virus. Same form can reflect same vision in this context. Other signifiers that emerge tend to decrease credibility of Bill Gates such as the cure will be worse than the desease. Signifieds of this data decline positive image of a public figure because this meme only focuses on negative manifestations of Bill Gates related to his concern involving COVID19 problems. Connotation reflected by signifiers refers to negative connotation

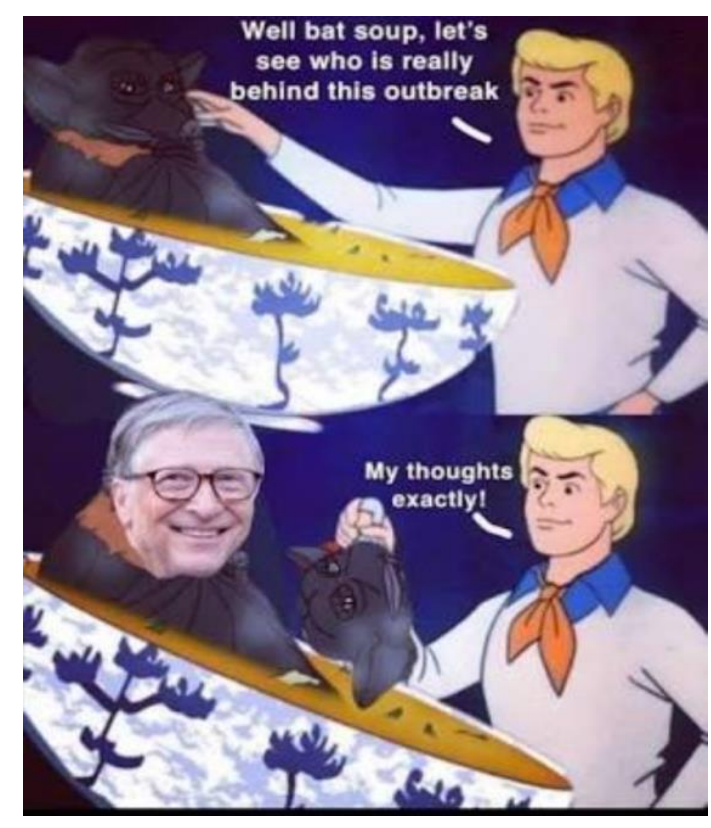

Fig. 2: Bill Gates behind Outbreak

A bowl of bat soup, Fred (a character of Scooby Doo cartoon) and Bill gates' face are involved in a construction of meaning. Those are visual signifiers that can inform an opinion related to COVID19 issue even without the written one. Bill gates' smiling face located in bowl clarify the antagonist impression for some people. The meme conveys explicitly a man behind the pandemic namely Bill Gates by placing the face in a bowl of soup. Fred as investigator can be hoped man who emerges afterward. Connotation reflected contains negative manifestation that explicate Bill Gates as the more responsible man than a bat soup.

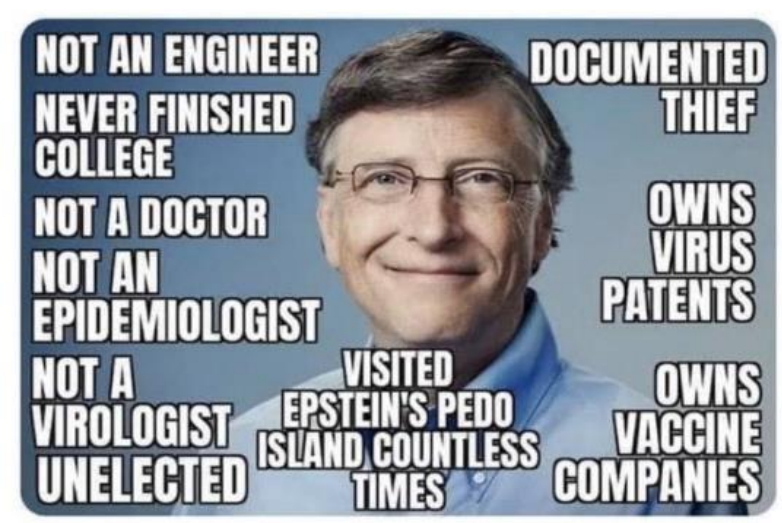

\section{Fig. 3: Bill Gates and his background}

Signifiers conveyed in written form reflect track record which stress Bill Gates position as non-medical background in the meme. They explicate that he is not a doctor, epidemologist, engineer, etc. and shape a stereotype of the figure in finding COVID-19 vaccines. The paradox of Bill Gates position appeared in data through noting documented thief, own virus patents, and owns vaccine companies, stimulates distrust vocalized by this meme. Those signifiers evoke irrational condition of Bill Gates related to his background and hesitate his pace and motives. Irrelevant track record denoted and bad past of Bill Gates shape negative association to who can find this meme. Those do decrease credibility of what Bill Gates is executing 
to find COVID-19 vaccines. Connotation in this meme contains negative manifestation.

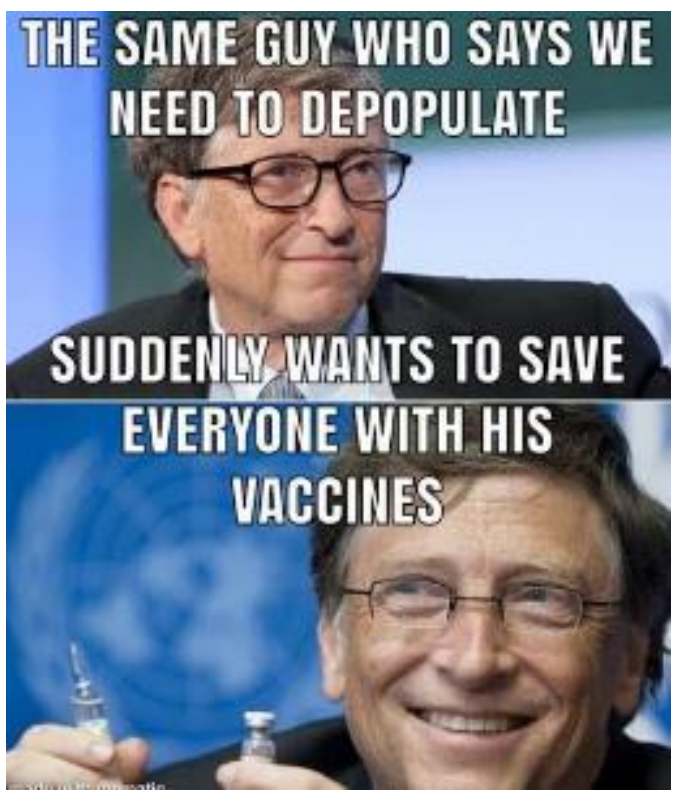

Fig. 4: Bill Gates and vaccines

This meme reveals Bill Gates' idea ever documented to care of global population of human being in written signifier by the same guy who says we need to depopulate. It furthermore evokes paradoxical impression between depopulating and saving through producing vaccines in this meme. Those written signifiers finally stimulates to think that seeking benefits with vaccines is Bill Gates' target. Connotative meaning is conveyed simultaneously with distrust of the figure. Conveyed by the written form, the utterance suddenly wants to save everyone with his vaccines is manifestation of distrust related to track record of Bill Gates.

\section{THINK MY BORONAUIRUS} IS KILLER?

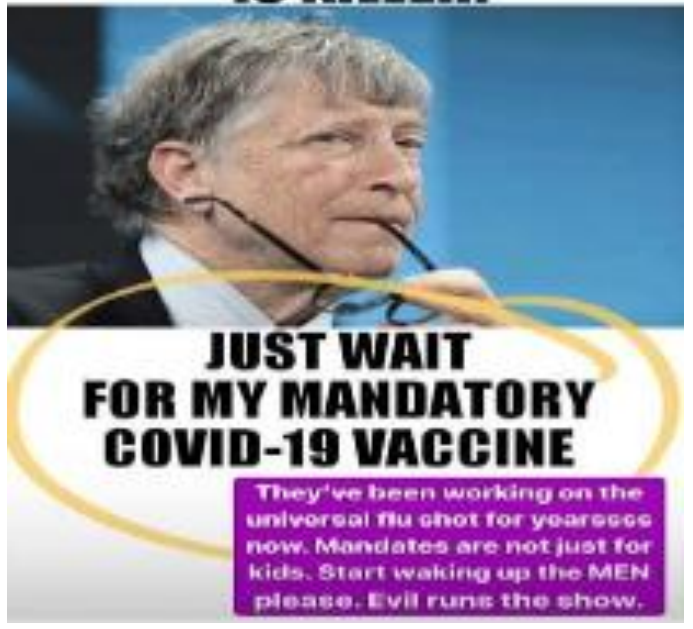

Fig. 5: Bill Gates and mandatory vaccines

In this meme, accusation of COVID-19 mastermind clearly refes to Bill Gates through written signifiers marked by possession form in phrase my coronavirus. The other signifiers like my mandatory COVID-19 vaccine reflect that opportunis impression also refers to him to persuade public in thinking that only business expansion is the motive. The assumption emerges because to sell vaccines, there must be viruses firstly. Connotation is evoked by negative manifestation in the meme.

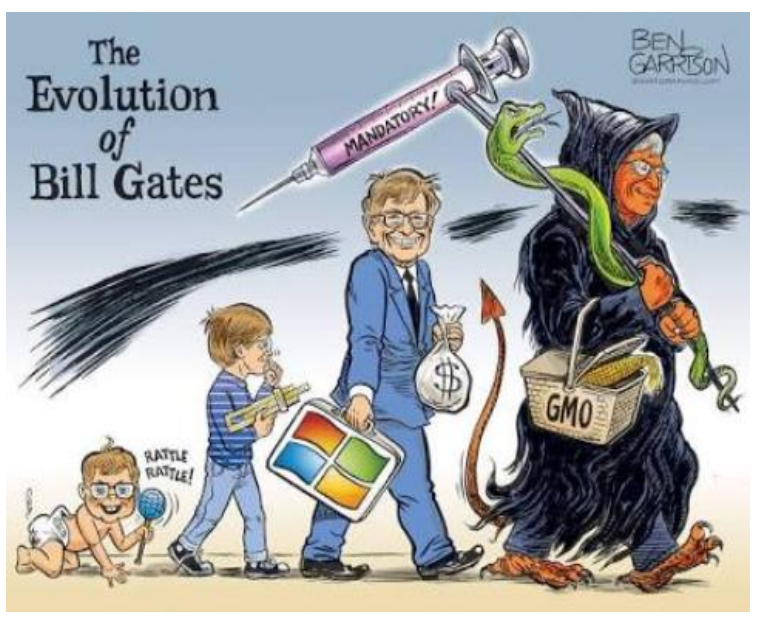

Fig. 6: Evolution of Bill Gates 
Signifiers reflect a consitent idea of Bill gates evolution in visual and written form. Evolution starts from a baby to an adult but before the last evolution as witchdoctor, a billionare with his money transform to be traditional witchdoctor and technological medical tools namely injection and GMO (genetically modified organisms). Both two medical tool can result unknown unintended consequences to human being. Those signifiers enhance negative impression that reflects negative connotation.

\section{THINES I TRU5T MDRE THAN \\ A VACCINE FROM BILL EATES.}

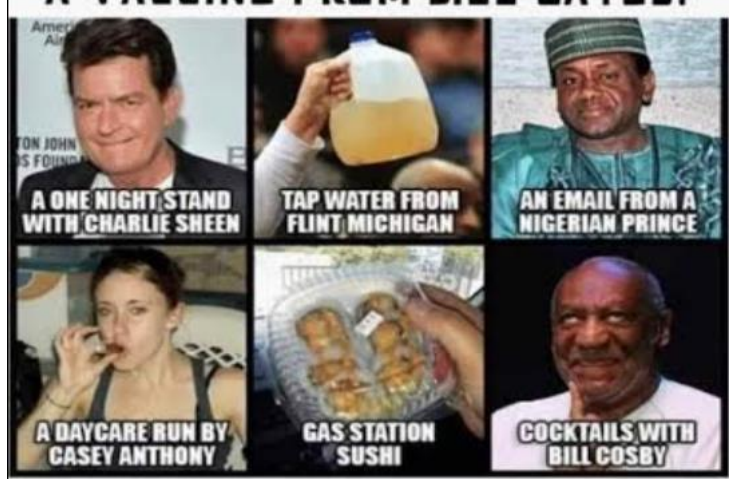

Fig. 7: Vaccine from Bill Gates

Signifiers in visual and writtern form compare thing trusted by some people and a vaccine of Bill Gates. Memes creator show his distrust of Bill Gates' vaccine to express and reject future existance of the the vaccine. Through only denoting things than future vaccine from Bill Gates in visual way, this meme reflect negative connotation. The distrust found here relates to the microchips inside vaccine that can track people (Spencer, 2020). Although some media defend Bill Gates from negative issues throgh clarifying but the memes become valid manifestation of distrust in internet public opinion.

\section{Discussion}

Undescribed memes reflect similar patterns of manifestation such as Bill Gates and vaccines or he and opportunist characteristics. The interpretation of data predominantly refer to repeated written signifiers and visual signifiers represented in whole memes to acquire a valid interpretation. Several data contain visual signifier and written signifier that support each other to acquire signified in a data such as Bill Gates in virus form who injects an old man with the explanation the cure will be worse than the desease. Signifiers reflect predominatly negative assosiations related to Bill Gates. It explicates negative connotation that exists consistently and it can transform to be myth in memes.

After acquiring signifieds, this study explicates the myths related to Bill Gates and what affiliates to him in the memes because the connotation has alreadly constructs constant pattern. Associating particular signifiers to Bill Gates in whole data refer to Bill Gates' negative track record, past ideas, ambitions, and pace. Those 4 points reflected by signifiers in memes are patterns affiliated to cultural practice in memes. The signification through revealing connotation encompasses emergence of myth in Reddit website users. Stereotypes are defined based on findings in whole memes. These are the myths that represent negative stereotypes.

\section{Bill Gates's vaccine as a danger}

Bill gates is assumed as a person affiliated to other grup behind with bad motives on the pandemic. As central figure portrayed in that group, he tries to find vaccines with interests. His existence with the others threatens the environment, particularly USA. 
Microchip issue also increase negative impression of Bill Gates. It refers to only personal ambition behind finding vaccines.

\section{Bill Gates as a mastermind}

A man behind the pandemic that plans complex activities evoked by using depopulating issue. To control population, a pandemic is created to reach global control. Selling vaccines also becomes other motive found behind the outbreak of pandemic.

\section{Bill Gates as an opportunist}

Affiliating to his background as one of American billionares, the impression of money-oriented emerges. Expansion of business is assumed to reach vaccine business that will result numerous profits. Paradoxical impression represented contains unconvincing pace. With irrelevant background, he emerge to fund medical programme but memes convey not the generosity, the negative motives. Distrust emerges because of negative impression in the figure.

\section{CONCLUSION}

Memes in Reddit website reflect negative connotation that shape Bill Gates figure in conspiracy issue related to COVID-19. Myths emerge to connect him with his negative track record, past ideas, ambitions, and pace. Bill Gates's vaccine as a danger, Bill Gates as a mastermind behind the pandemic, and Bill Gates as an opportunist who concerns on expansion of business to reach vaccine business become myths spreaded in digital room. Finally people can filter various opinions to face conspiracy issue based on their own ways. Objective facts that can be tracked in various source are available, but there are facts by man agreement. Things can exist in a sense because our belief on them (Searle, 1996). This study reflect myths and their patterns that affiliates a signifier and other signifier. As a suggestion, futher study related to myth in memes can reach ideological emanifestation.

\section{REFERENCES}

Aditya Achadiat, R. (2013). The Representation of Americanization Myths in the Internet Memes on the 9gag Comedy Website. Passage 1(2), 45 - 54.

Allen, G. (2003). Roland Barthes. New York: Routledge.

Barkun, M. (2003). A Culture of Conspiracy. Berkeley and Los Angels: University of California Press.

Barthes, R. (1967). Elements of Semiology (translated from the French by Annette Lavers and Colin Smith). New York: Hill and Wang.

Barthes, R. (1972). Mythologies (English Translation). New York Farrar, Straus and Giroux: The Noonday Press .

Benaim, M. (2018). From Symbolic Values to Symbolic Innovation: Internetmemes and Innovation. Research Policy.

Cannizzaro, S. (2016). Internet Memes as Internet Signs: a Semiotic View of Digital Culture. Sign Systems Studies 44(4), 562-586.

Clement, J. (2020, March). Reddit Users: Unique Monthly Visits 2019. Dipetik June Saturday, 2020, dari Statista: https://www.statista.com

Danesi, M. (2004). Messages, Signs, and Meanings 3rd edition. Toronto: Canadian Scholars' Press Inc.

Danesi, M., \& Perron, P. (1999). Analyzing Culture. Indiana: Indiana University Press.

Dewi, R. S., Abdulllah, A., Maryani, E., \& Suganda, D. (2017). Internet Memes : Representation of 
Indonesian Political Culture $\mathrm{n}$ Jakarta Gubernatorial Election 2017. Advances in Economics, Business and Management Research (AEBMR), volume 43 .

Foss, S. K. (2004). Defining visual rhetorics Mahwah. Dalam C. A. (Eds.), Framing the study of visual rhetoric: Toward a transformation of rhetorical theory (hal. 303-313). N.J.: Lawrence Erlbaum Associates. Huntington, H. E. (2013). Subversive Memes: Internet Memes as a Form of Visual Rhetoric. Selected Papers of Internet Research 14.0.

Kilpinen, E. (2008). Memes Versus Signs: on the Use of Meaning Concepts about Nature and Culture. Semiotica 171-1/4, 215-237.

Mcilwain, C. D. (2007). Race, Pigskin, and Politics: a Semiotic Analysis of Racial Images in Political Advertising. Semiotica 167-1/4, 169-191.

Octavita, R. A., \& Zaimar, Y. S. (2018). Semiotic Analysis Of Satire Meme Connecting Women's Identity In Brillio Net .Journal of English Language Teaching Volume 03, Issue 01, September , 38-45.

Rose, G. (2016). Visual Methodologies (Fourth Edition). Los Angels, London, and New Delhi: Sage Publication.

Ross, A. S., \& Rivers, D. J. (2017). Digital Cultures of Political Participation: Internet Memes and the Discursive Delegitimization of the 2016 U.S Presidential Candidates. Discourse, Context and Media.

Salam, A. (2018). The Hoax Phenomenon in Indonesian Society:Observing Anti-Diversity Memes since 2014. Humaniora volume 30, 315-324.

Searle, J. R. (1996). The Construction of Social Reality. London, New York, Toronto: Penguin Group.
Sebeok, T. A. (2001). Signs: An Introduction To Semiotics (Second Edition) . Toronto Buffalo London: University Of Toronto Press .

Semenenko, A. (2018). The Power Of Myth: Mikhail Zhvanetskii's Satire In Soviet And Post-Soviet Russia. Russian Literature 95, 93-122.

Shalini, A. (2020, April Thursday). Dipetik June Thursday, 2020, dari CNBC Indonesia Youtube Channel: hhttps://youtu.be/uMJDjheUHaU

shifman, l. (2014). Memes in Digital Culture (Third Edition). London: The MIT Press.

Shteynman, M. (2016). Political Myth And Political Glory: Shaping Media Reality . Russian Sociological Review Vol.15. No4, 96-113.

Spencer, S. H. (2020, April Tuesday). Conspiracy Theory Misinterprets Goals of Gates Foundation. Dipetik June Tuesday, 2020, dari factcheck.org: www.factcheck.org

Thibault, M. (2016). Trolls, Hackers, Anons Conspiracy Theories in the Peripheries of the Web. Lexia Rivista di semiotica, 23-24.

Varis, P. (2015). Conviviality and Collectives on Social Media: Virality, Memes, and New Social Structures . Multilingual Margins 2(1) , 31-45.

Walker, R. (2008). Cultural Memes,Innate Proclivities and Musical Behaviour: a Case Study of the Western Traditions. Society for Education, Music and Psychology Research vol 32, 153-190.

Wiggins, B. E. (2019). The Discursive Power of Memes in Digital Culture Ideology, Semiotics, and Intertextuality. New York: Routledge . 